\title{
Changes in Muscle and Collagen Fibers of Fish after Exposure to Urban Pollutants and Biodegradable Detergents
}

\author{
Cynthia Medina Ciamarro ${ }^{1}$, Bruno Fiorelini Pereira ${ }^{2}$, Rebeca Mamede da Silva Alves ${ }^{1}$, \\ João Rodolfo Tuckumantel Valim ${ }^{1}$, Dimítrius Leonardo Pitol ${ }^{3 *}$, Flávio Henrique Caetano ${ }^{1}$ \\ ${ }^{1}$ Instituto de Biociências, Universidade Estadual Paulista "Júlio de Mesquita Filho" — UNESP, Campus Rio Claro, \\ Rio Claro, Brazil \\ ${ }^{2}$ Centro de Ciências Biológicas e da Saúde, Universidade Federal do Oeste da Bahia-UFOB, Campus Barreiras, \\ Barreiras, Brazil \\ ${ }^{3}$ Faculdade de Odontologia de Ribeirão Preto, Universidade de São Paulo-FORP/USP, Campus Ribeirão Preto, \\ Ribeirão Preto, Brazil \\ Email: dimitrius@forp.usp.br
}

Received 26 May 2015; accepted 30 June 2015; published 3 July 2015

Copyright @ 2015 by authors and Scientific Research Publishing Inc.

This work is licensed under the Creative Commons Attribution International License (CC BY).

http://creativecommons.org/licenses/by/4.0/

(c) (i) Open Access

\section{Abstract}

Fish populations are sensitive to environmental impact resulting from many factors, as an introduction of exotic species, industrial or residual waste, oil spills, pesticides or other agents that can directly affect the ecology and species survival. Astyanax altiparanae is pelagic and active swimmer specie and can have serious implications on its way of life as changes in muscle structure of fish may occur since the presence of pollutants in the water. In this study we analyze the alterations in Muscle and collagen fibers of the pectoral muscles and pollutants exposed flows contained in water with biodegradable detergents, and water coming from the Blue Lake, River clear-SP $\left(2^{\circ} 24^{\prime} 39^{\prime \prime} \mathrm{S}, 4^{\circ} 33^{\prime} 39^{\prime \prime} \mathrm{E}\right)$ diluted. Effects of these exposures were analyzed during the period of seven and thirty days. Compared with acclimatized fish (Astyanax altiparanae) with pure water from an artesian well, the muscle fibers morphology and collagen concentration on them have changed due to the exposure to urban pollutants and biodegradable detergents.

\section{Keywords}

\section{Astyanax altiparanae, Biodegradable Detergents, Pollutants}

\footnotetext{
${ }^{*}$ Corresponding author.

How to cite this paper: Ciamarro, C.M., Pereira, B.F., da Silva Alves, R.M., Valim, J.R.T., Pitol, D.L. and Caetano, F.H. (2015) Changes in Muscle and Collagen Fibers of Fish after Exposure to Urban Pollutants and Biodegradable Detergents. Microscopy Research, 3, 33-40. http://dx.doi.org/10.4236/mr.2015.33005
} 


\section{Introduction}

Muscle tissues generate and transmit power and can be formed by several types of muscle cells such as skeletal, cardiac or smooth muscle cells. Fish muscles are mostly striated, comprising from $40 \%$ to $75 \%$ of the animal's weight [1] [2]. In fish, muscle fibers are distributed in different areas or compartments, while in mammals there is mosaic pattern of distribution [1]. Another important characteristic of the fish muscular system is multiplyinnervated contractile fibers. Involving these fibers is connective tissue which holds them together and myomeres are separated by connective tissue sheaths called myosepts [3], though architectural details such as muscular and connective tissue anatomy and tissue relations in myomeres are not well known. Collagen is the main constituent of connective tissue in fish muscles. Firmness of the muscle is directly related to its collagen content [4] [5]. Skeletal muscle constitutes the majority of edible parts of fish and in addition, striated muscle includes muscles associated with fin movement [6]. Physiological roles of red muscle are different from those of white muscle. Red muscle is laterally located in the animal's body, it extends toward the spine and turns dark red in sites of high myoglobin concentration [3] [7]. In fish, red muscle has a higher lipid content than white muscle, a greater number of mitochondria per cell and higher respiratory rate; red fibers are aerobic with slow contraction [8]. Red muscle is used to power slow sustainable swimming, however, when swimming speed increases, there is progressive recruitment of white muscle, representing a power reserve for short high speed swimming [9]. In some species of fish white muscle is an important fraction of an animal's total mass, and may represent from $80 \%$ to $100 \%$ at a given point of a transversal section. White muscle is responsible for short, strong bursts of motion, which occur during food capture or predator escape. White fish muscles have low amounts of mitochondria, lower respiratory rates and get fatigued faster than red fibers; furthermore, they are anaerobic, with glycolytic metabolism [1] [8]. Red/white fiber ratio in a fish's body is related to lifestyle, thus pelagic fishes have higher proportions of red fibers while white muscle fibers predominate in benthic fishes [7] [10]. This dependence on swimming speed and lifestyle reflects a flexibility in muscle morphology that makes it useful as a tool for environmental assessment, especially in cases where swimming speed can be impaired by pollutant exposure. Our target specie, Astyanax altiparanae, also known as yellow tail lambarior tambiú, is commonly consumed, however its commercial value is only average due to its small size, despite its great ecological value as foraging specie [11] [12]. The specie is characterized by a silver body, with a ventral region, gray dorsal region and yellow caudal, anal and pelvic fins, with the rest being hyaline or slightly yellow [13]. Fish populations are sensitive to a variety of environmental impacts including oil spills, pesticides and industrial residues, which can directly affect ecology and survival. Our urban contaminants come from a lake located in an urban area of the city of Rio Claro (SP-Brazil) called Lago Azul (2 $\left.2^{\circ} 4^{\prime} 39^{\prime \prime} \mathrm{S}, 47^{\circ} 33^{\prime} 39^{\prime \prime} \mathrm{E}\right)$. The lake was formed by an impoundment of a stream called "Servidão", located in the same area and currently receives a high dose of contaminants from urban sewage and industrial residues. One of the most common water contaminants are biodegradable detergents and the majority of detergents in the market are dodecyl benzene sodium sulfonate-based [14]. Although biodegradable detergents are considered mild, they are under criticism. In this study, we analyzed morphological changes in red and white fibers of the pectoral and tail muscle of Astyanax altiparanae exposed to biodegradable detergents and polluted water from an urban lake.

\section{Material and Methods}

Sixty individuals of Astyanax altiparanae were kept in three 500 liters aerated polyethylene water tanks, twenty individuals in each tank. One group (treatment 1 ) was exposed to water from the urban lake (Lago Azul), another (treatment 2) was exposed to a 1ppm dilution of ten brands of biodegradable detergent And the control group was exposed to clean, chlorinated water from an artesian well at UNESP-Campus of Rio Claro. Specimens were sampled after 7 and 30 days of exposure. They were anesthetized with $0.1 \mathrm{~g}$ benzocaine diluted in $1 \mathrm{ml}$ of ethanol per $100 \mathrm{ml}$ of deionized water. Fragments were extracted from pectoral and caudal muscles, fixed with Bouin's solution, dehydrated in alcohol, embedded in historesin and sectioned with Leica's RM2245 microtome. [15]

\subsection{Muscle Fiber Diameter}

Diameter variations in muscle fibers were analyzed in Hematoxylin-Eosin stained slides, prepared according to Paulete and Beçak [16]. Five images of five cross sections of each individual were captured with Leica DM2000 microscope in 100× magnification and a total of 800 muscle fibers were measured with ImageJ@ (Figure 1(D)). 

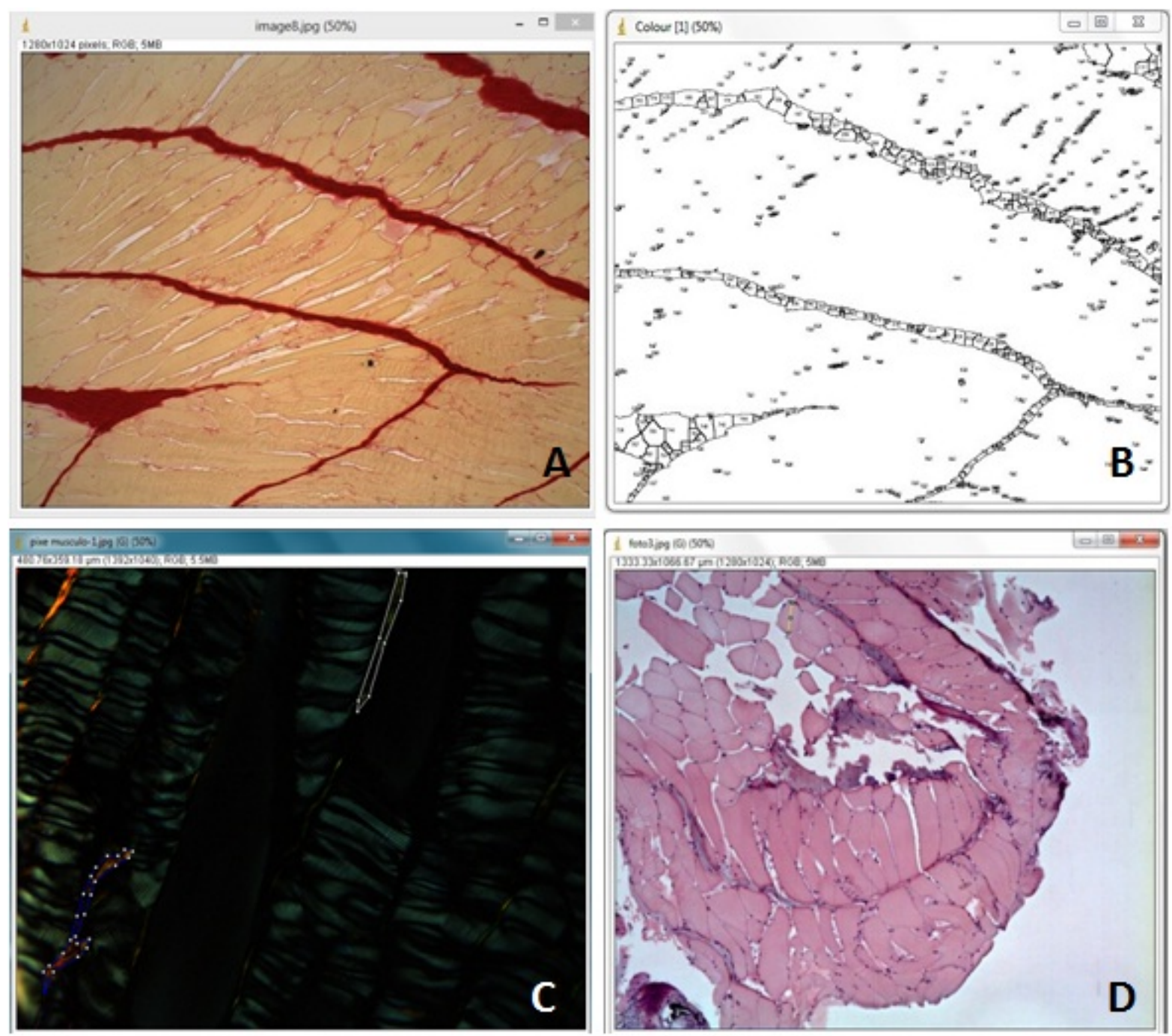

Figure 1. Quantitative analysis of the images through software ImageJ. (A) fish muscle stained with picrosirius, showing collagen fibers in 100× magnification; (B) fish muscle stained with picrosirius, showing collagen-occupie areas marked and quantified on ImageJ(C; (C) fish muscle stained with picrosirius in polarized light with type I (red) and type III (green) collagen areas defined and quantified with ImageJ(C) (D) fish muscle stained with H.E., showing fiber diameter measured in ImageJ(C.

\subsection{Quantitative Analysis of Collagen Fibers}

Two photos per section were analyzed in slides stained by Picrosirius's method according to Pearse [17] in bright field polarized light with a Leica DM2000 microscope. The area occupied by total collagen and the area occupied by type I and III collagen differentiated by polarization was measured in ImageJ@ and statistically compared (Figures 1(A)-(C)).

\subsection{Chemical Analysis of Water}

Water samples from all groups were analyzed by the laboratories of the Geology Department of UNESP-Campus of Rio Claro (Laboratório de Análise de Águas do Departamento de Geologia Aplicada do Instituto de Geociências e Ciências Exatas), following the rules of the Standard Methods for the Examination of Water and Wastewater for the parameters described below:

Metal determination was performed by ICP-AES for Mg, Ca, Sr, Ba, Cr (t), Mn, Fe, Co, Ni, Cu, Zn, Cd, Si, P (t) and $\mathrm{Pb}$. Anions: $\mathrm{F}^{-}, \mathrm{Cl}^{-}, \mathrm{NO}_{2}, \mathrm{NO}_{3}, \mathrm{PO}_{4}, \mathrm{SO}_{4}, \mathrm{ClO}_{2}^{-}$, acetate and oxalate plus cations $\mathrm{Li}, \mathrm{Na}, \mathrm{NH} 4$ and $\mathrm{K}$ 
were determined by ionic chromatography. Analyzes of $\mathrm{pH}$, conductivity, total alkalinity and carbonate were performed by potentiometric titration.

Assessment of actual surfactant concentration was performed in all experimental groups for LAS (linear alkyl benzene sulfonate, a common surfactant of household detergents [14]) by chromatographic analysis in HPLC Agilent Technologies 1200 series, with fluorescence detector at consulting company (Global Análise \& Consultoria-São Carlos-SP-Brazil).

\subsection{Statistical Analysis}

Measurements of muscle fiber diameter and quantified collagen area were tested for normality with Shapiro Wilk and the means were compared by Kruskal-Wallis/Dunn's test in Biostat 5.0@.

\section{Results}

\subsection{Water Analysis}

Treatments 1 and 2 showed alkaline $\mathrm{pH}$, rising from $\mathrm{pH} 5.39$ in control to $\mathrm{pH} 6.04$ in detergent dilution and to $\mathrm{pH} 7.17$ in urban lake water, due to an increase in $\mathrm{HCO}_{3}^{-}$concentration, which ranged from $1.2 \mathrm{mg} \cdot \mathrm{L}^{-1}$ in control to $4.9 \mathrm{mg} \cdot \mathrm{L}^{-1}$ in detergent dilution and $59.3 \mathrm{mg} \cdot \mathrm{L}^{-1}$ in lake water. The detergent group also showed significant increase in $\mathrm{Na}\left(20.1 \mathrm{mg} \cdot \mathrm{L}^{-1}\right)$, and $\mathrm{Ni}\left(0.066 \mathrm{mg} \cdot \mathrm{L}^{-1}\right)$ compared to the other groups, and in $\mathrm{NO}_{2}^{-}(1.15$ $\left.\mathrm{mg} \cdot \mathrm{L}^{-1}\right)$ compared to control only. Water samples showed increased $\mathrm{F}-\left(0.40 \mathrm{mg} \cdot \mathrm{L}^{-1}\right), \mathrm{Cl}\left(\mathrm{mg} \cdot \mathrm{L}^{-1}\right)$ and $\mathrm{Fe}$ concentrations $\left(0.16 \mathrm{mg} \cdot \mathrm{L}^{-1}\right)$ compared to the other groups, and increase in $\mathrm{NO}_{2}^{-}$concentration $\left(0.86 \mathrm{mg} \cdot \mathrm{L}^{-1}\right)$ compared to control. Regarding LAS concentration, detergent dilution had $0.375 \mathrm{mg} \cdot \mathrm{L}^{-1}$ of surfactant and lake water sample, $0.33 \mathrm{mg} \cdot \mathrm{L}^{-1}$ of surfactant.

\subsection{Muscle Fiber Diameter}

Diameter measures of white caudal muscle fibers of fish exposed to pollutants for 7 days showed no statistical differences when compared to control group (Figure 2 and Figure 3). However, white pectoral muscle fibers

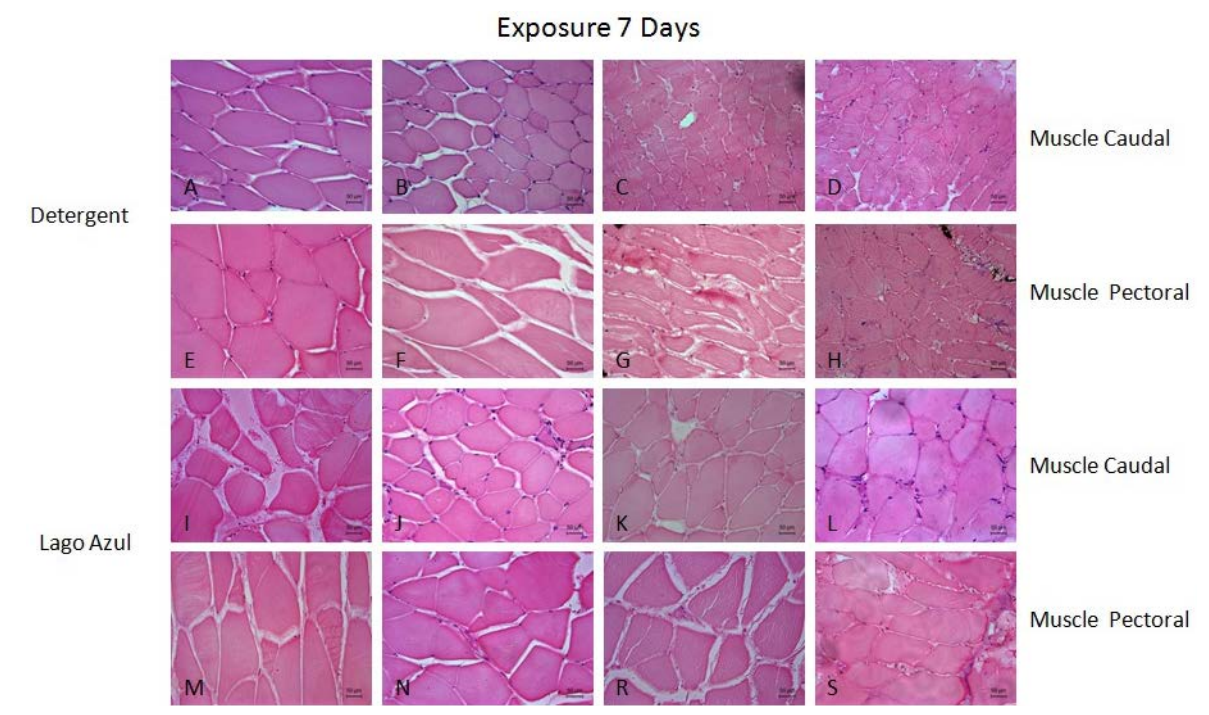

Figure 2. Photomicrograph of caudal and pectoral muscle with exposure of 7 days for treatments (1) and (2) stained with hematoxylin and Eosin. (A) White muscle caudal exposed to treatment with biodegradable detergents; (B) white muscle caudal control treatment; (C) red muscle caudal exposed to treatment with biodegradable detergents; (D) red muscle Caudal control treatment; (E) white pectoral muscle exposed to treatment with biodegradable detergents; $(\mathrm{F})$ pectoral muscle white control treatment; (G) red pectoral muscle exposed to treatment with biodegradable detergents; $(\mathrm{H})$ pectoral muscle red control treatment; (I) white caudal muscle exposed to treatment with water Lago Azul; (J) white muscle caudal control treatment; (K) red white muscle caudal exposed to treatment with water Lago Azul; (L) red muscle caudal control treatment; (M) white pectoral muscle exposed to treatment with water Lago Azul; $(\mathrm{N})$ pectoral muscle white control treatment; (R) red pectoral muscle exposed to treatment with water Lago Azul; (S) pectoral muscle red control treatment. 
Exposure 30 Days

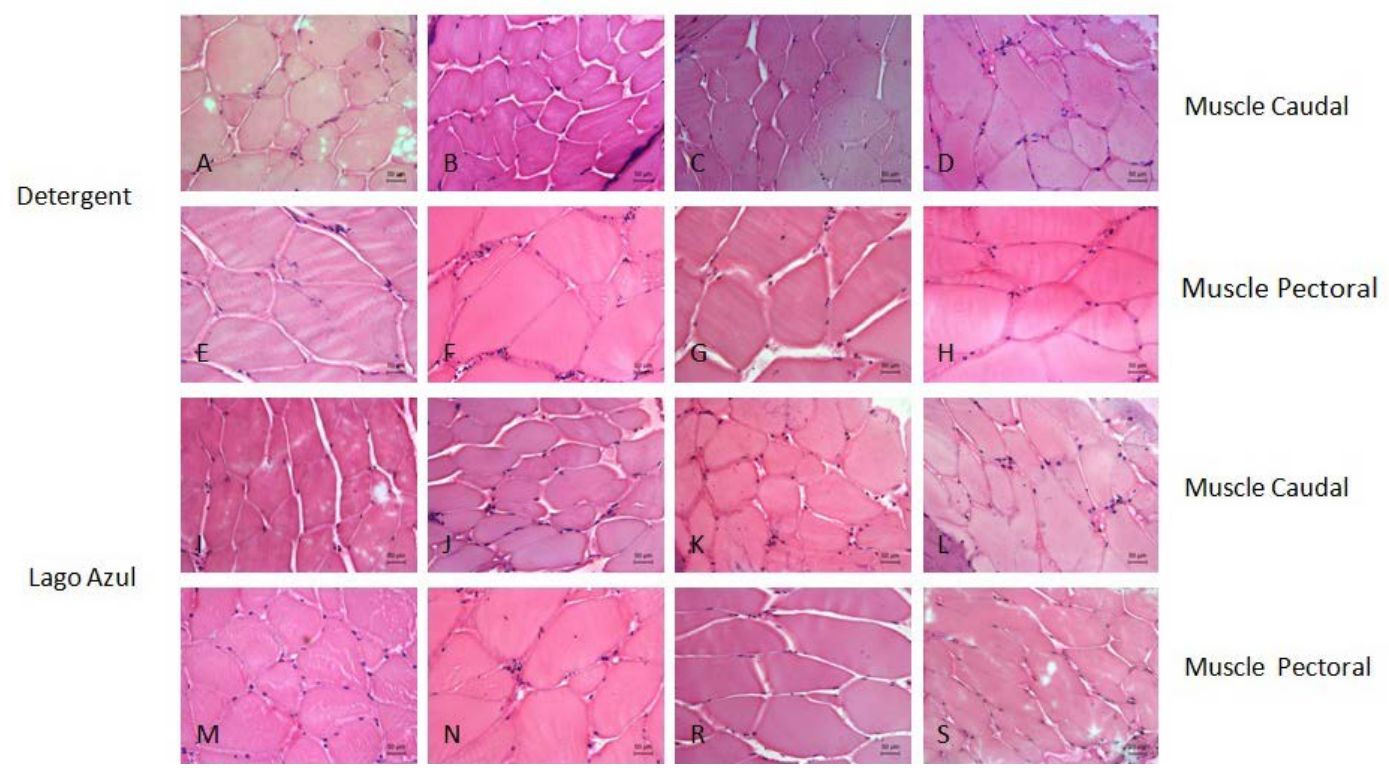

Figure 3. Photomicrograph of caudal and pectoral muscle with exposure of 30 days for treatments (1) and (2) stained with hematoxylin and Eosin. (A) White muscle caudal exposed to treatment with biodegradable detergents; (B) white muscle caudal control treatment; (C) red muscle caudal exposed to treatment with biodegradable detergents; (D) red muscle Caudal control treatment; (E) white pectoral muscle exposed to treatment with biodegradable detergents; (F) pectoral muscle white control treatment; $(\mathrm{G})$ red pectoral muscle exposed to treatment with biodegradable detergents; $(\mathrm{H})$ pectoral muscle red control treatment; (I) white caudal muscle exposed to treatment with water Lago Azul; (J) white muscle caudal control treatment; (K) red white muscle caudal exposed to treatment with water Lago Azul; (L) red muscle caudal control treatment; (M) white pectoral muscle exposed to treatment with water Lago Azul; $(\mathrm{N})$ pectoral muscle white control treatment. (R) red pectoral muscle exposed to treatment with water Lago Azul; (S) pectoral muscle red control.

showed a significant difference of $\mathrm{p}<0.05$ in detergent groups and $\mathrm{p}<0.01$ in lake water group (Figure 4 and Figure 5). There was an increase of fiber diameters in detergent groups compared to control. Red caudal musculature showed no statistical difference among groups, but red pectoral muscle showed significant reduction (p $<0.05$ ) in groups exposed to detergent). Statistical analysis of muscle fibers, in red and white caudal muscle and in red and white pectoral muscle of the fishes that were exposed to pollutants during the period of 30 days (Time 2) showed no significant difference with $p=0.5225$ in white caudal muscle, $p=0.7834$ in white pectoral muscle, $\mathrm{p}=0.2558$ in red caudal muscle and $\mathrm{p}=0.7897$ in red pectoral muscle.

\subsection{Quantification of Collagen Fibers}

Statistical analysis showed no significant difference in collagen area in white and red caudal muscle fibers and white and red pectoral muscle fibers exposed to pollutants for 7 days, with $p=0.0947$ in white caudal muscle, $p$ $=0.587$ in white pectoral muscle, $p=0.06$ in red caudal muscle, $p=0.0319$ in red pectoral muscle (Figure 4 and Figure 5). Similarly, statistical analysis showed no difference for 30 days of exposure in any of the groups: white caudal muscle $\mathrm{p}=0.2636$, white pectoral muscle $\mathrm{p}=0.5841$, red caudal muscle $\mathrm{p}=0.0616$ and red pectoral muscle $\mathrm{p}=0.1504$.

\subsection{Type I and Type III Collagen Total Area}

Statistical analysis showed significant decrease $(p<0.01)$ in type I collagen area for 7 day exposure of white caudal muscles in both contaminated groups. Red pectoral muscle also showed significant decrease in type I collagen area in groups exposed to detergent $(p<0.05)$ and to lake water $(p<0.01)$. Red caudal musculature showed no significant differences in any statistical comparison $(p=0.0572)$ and red pectoral muscle fibers, showed a significant reduction of type I collagen in groups exposed to lake water $(\mathrm{p}<0.01)$. Caudal muscle fibers showed no statistical differences in type III collagen area in any of the groups $(\mathrm{p}=0.736)$. White pectoral 

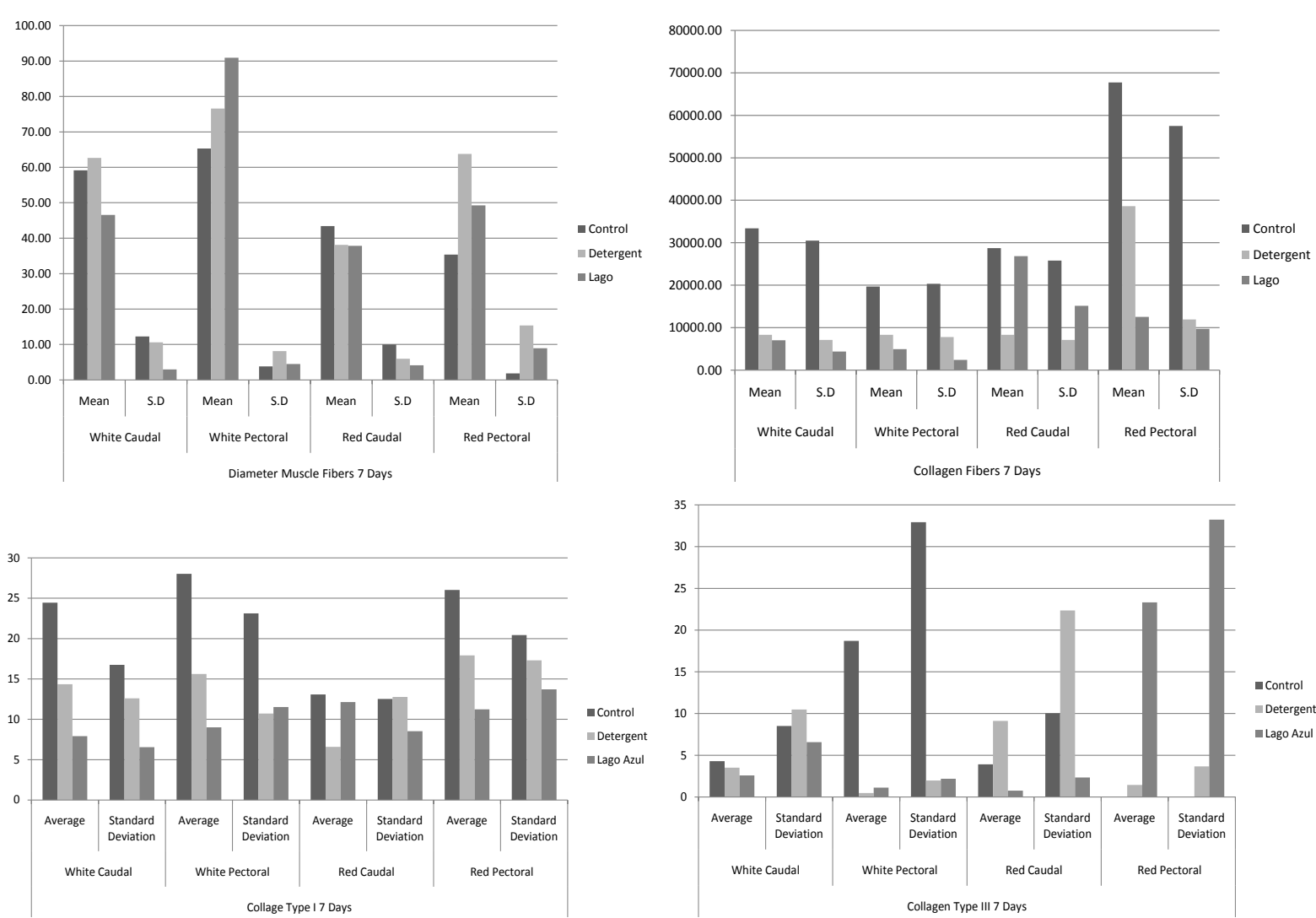

Figure 4. Analyze quantitative muscle and collagen fibers, and area occupied by fibers of collagen type I and III with exposure to 7 days treatment (1) and (2).

muscle fibers showed a significant decrease in type III collagen area $(\mathrm{p}<0.01)$ on both detergent and lake water groups when compared to control group. Regarding red caudal muscle, no significant differences were found between groups $(\mathrm{p}=0.0709)$ and there was no type III collagen in red pectoral muscle fibers (Figure 4 and Figure 5).

Exposure to pollutants for 30 days caused a decrease of type I collagen area in white caudal muscle fibers in both contaminated groups, while white pectoral muscle fibers showed statistical difference in collagen area in any of the groups. Red caudal muscle only showed statistical difference when compared to groups exposed to detergent. Red pectoral muscle fibers showed significant reduction of type I collagen area in groups exposed to lake water, but not in groups exposed to detergent. Exposure to lake water and detergent for 30 days caused no significant variation in type III collagen area in any of the muscles analyzed (Figure 4 and Figure 5).

\section{Discussion}

According to Barillet et al. [17], morphometric analysis of muscle tissue can be a reliable indicator of uranium toxicity and probably of other types of toxicity such that of detergents and other pollutants found in contaminated urban lakes, as the one we studied. In fact, our experiments showed small differences in muscle fibers after seven days of treatment and support the use of muscle morphology as a tool for toxicity assessment. Muscle injuries are potentially inducible markers of environmental contamination and degenerative traits such as muscle atrophy, broken myofibrils, swollen sarcolemma lnucleous and sarcoplasmic reticulum have been described as symptoms of exposure to contaminants such as pesticides and metals [17]. Thus, significant variations found in muscle fiber measurements from seven days of exposure could indicate a possible dilation due to pollutants in the water as can be confirmed by the data of white pectoral muscles. Studies have shown the presence of types I and type V collagen in several species of fish, but in Salmoirideus only type I collagen was detected in musculature [18]. Collagen is a major constituent of intramuscular connective tissue in fish and it has an important role in the texture of meat from these animals [5]. Intramuscular connective tissue degradation causes softening of 

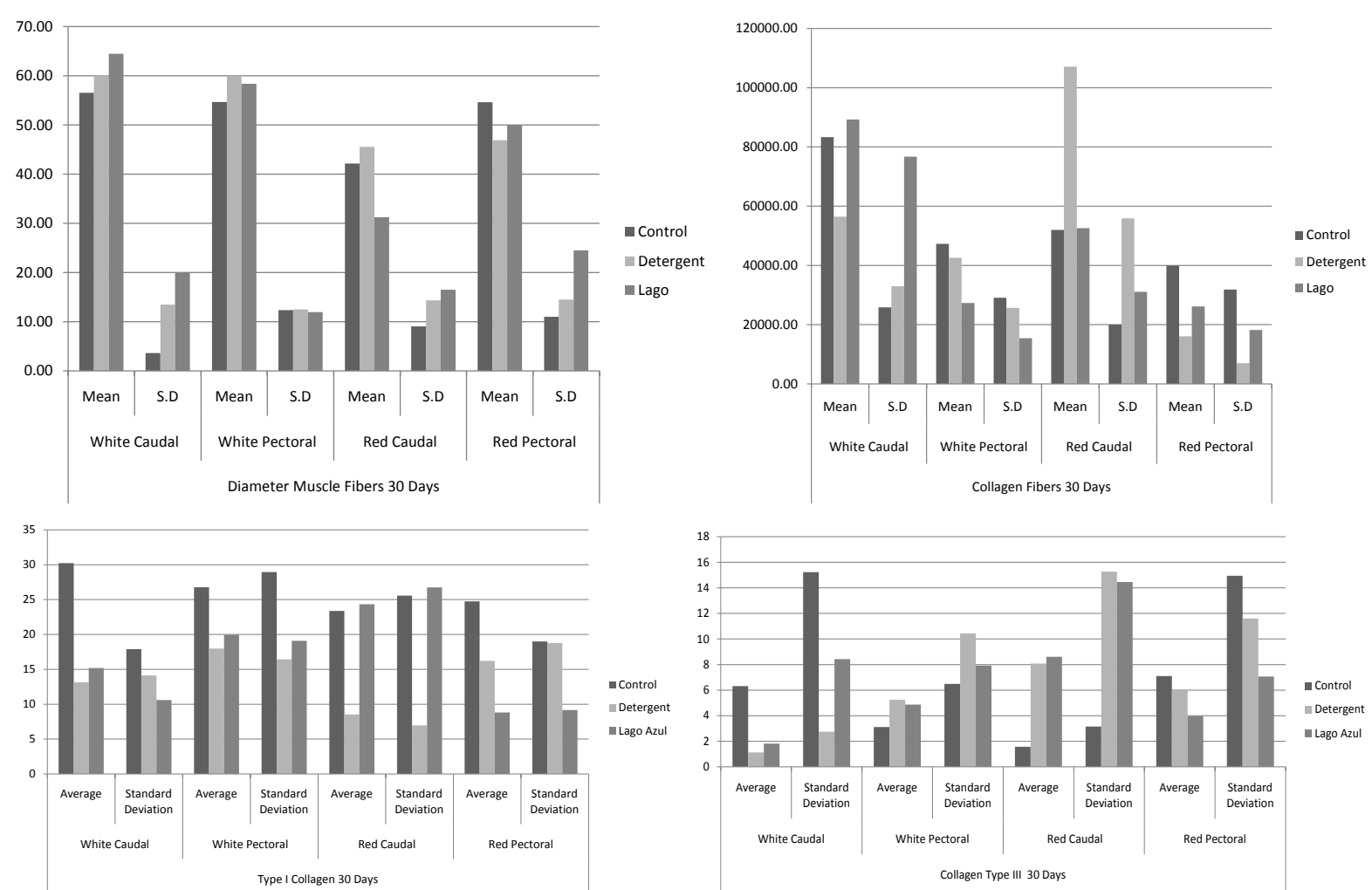

Figure 5. Analyze quantitative muscle and collagen fibers, and area occupied by fibers of collagen type I and III with exposure to 30 days treatment (1) and (2).

fish muscle. Thus, changes in collagen in muscle fibers can have serious implications for the animal and the quality of the meat [19]. Our results did not indicate significant changes in total collagen-occupied area in pollutant-exposed individuals. In bones, type I collagen is abundant, although types III and V are also present in smaller amounts [20]. Similarly, regarding muscles, our experiments showed that between type I and type III collagens, type I collagen was significantly more abundant in both red and white muscle.

\section{Conclusion}

Muscular-tissue morphology of Astyanax altiparanae changed due to exposure to urban pollutants and biodegradable detergents. Changes in fiber diameter were observed in white and red muscles and in caudal and pectoral muscles. There were also significant differences in collagen-occupied area for types I and III collagen, which makes muscle fiber morphology a useful tool for environmental assessment.

\section{References}

[1] Carani, F.R., Aguiar, D.H., De Almeida, F.L.A., Gonçalves, H.S., Padovani, C.R. and Dal Pai-Silva, M. (2008) Morfologia e crescimento do músculo estriado esquelético no pirarucu Arapaima gigas Cuvier, 1817 (Teleostei, Arapaimidae). ActaScientiarum. Biological Sciences, 30, 205-211.

[2] Schmidt-Nielsen, K. (2010) Fisiologia Animal-Adaptação e Meio Ambiente. 5th Edition, Livraria Santos Editora, São Paulo.

[3] Santos, V.B. (2007) Aspectos morfológicos da musculatura lateral dos peixes. Boletim do Instituto de Pesca, 33, 127135.

[4] Sato, K., Yoshinaka, R., Itoh, Y. and Sato, M. (1989) Molecular Species of Collagen in the Intramuscular Connective Tissue of Fish. Comparative Biochemistry and Physiology, 92B, 87-91. http://dx.doi.org/10.1016/0305-0491(89)90317-9

[5] Suarez, M.D., Abad, M., Ruiz-Cara, T., Estrada, J.D. and García-Gallego, M. (2005) Changes in Muscle Collagen Content during Post Mortem Storage of Farmed Sea Bream (Sparus aurata): Influence on Textural Properties. Aqua- 
culture International, 13, 315-325. http://dx.doi.org/10.1007/s10499-004-3405-6

[6] Hibiya, T. (1982) An Atlas of Fish Histology-Normal and Pathological Features. Gustav Fischer Verlag, StuttgartHohenheim.

[7] Suzuki, T., Toshiyuki, H. and Suyama M. (1987) Free Imidazole Compounds in White and Dark Muscles of Migratory Marine Fish. Comparative Biochemistry and Physiology, 87B, 615-619. http://dx.doi.org/10.1016/0305-0491(87)90060-5

[8] Mumford, S., Heidel, J., Smith, C., Morrison, J., Macconnell, B. and Blazer, V. (2007) Fish Histology and Histopathology. 4th Edition, US Fish \& Wildlife Service, West Virginia.

[9] Wardle, C.S., Videler, J.J. and Altringham, J.D. (1995) Review Tuning in to Fish Swimming Waves: Body Form, Swimming Mode and Muscle Function. The Journal of Experimental Biology, 198, 1629-1636.

[10] Videler, J.J. (1993) Fish Swimming. Chapman \& Hall, London. http://dx.doi.org/10.1007/978-94-011-1580-3

[11] Nomura, H. (1975) Fecundidade, maturação sexual e índicegônado-somático de lambaris do gêneroAstyanax Baird e Girard, 1854 (Osteichthyes, Characidae), relacionados com fatoresambientais. Revista Brasileira de Biologia, 35, 775798.

[12] Godoy, M.P. (1975) Peixes do Brasil: Subordem Characoidei. Ed. Franciscana, São Paulo, 4.

[13] Gomieiro, L.M. and Braga, F.M.S. (2003) O lambari Astyanax altiparanae (Characidae) podeser um dispersor de sementes? Acta Scientiarum. Biological Sciences, 25, 353-360.

[14] Human and Environmental Risk Assessment (2009) LAS Human and Environmental Risk Assessment on Ingredients of European Household Cleaning Products: Linear Alkylbenzene Sulfonates. HERA, Brussels.

[15] Pereira, B.F., Alves, A.L., Senhorini, J.A., Rocha, R.C.G.A., Scalize, P.H., Pitol, D.L. and Caetano, F.H. (2014) Effects of Biodegradable Detergents in Morphological Parameters of Liver in Two Neotropical Fish Species (Prochilodus lineatus and Astyanax altiparanae). Microscopy Research, 2, 39-49. http://dx.doi.org/10.4236/mr.2014.22006

[16] Paulete, J. and Beçak, W. (1976) Técnicas de Citologia e Histologia. Livros Técnicos e Científicos, São Paulo, 2.

[17] Pearse, A.G.E. (1985) Histochemistry: Theoretical and Applied. 4th Edition, Churchill Livingstone, Edinburgh, London, Melbourne and New York.

[18] Barillet, S., Larnoa, V., Floriani, M., Devauxb, A. and Adam-Guillermina, C. (2010) Ultrastructural Effects on Gill, Muscle, and Gonadal Tissues Induced in Zebrafish (Danio rerio) by a Waterborne Uranium Exposure. Aquatic Toxicology, 100, 295-302. http://dx.doi.org/10.1016/j.aquatox.2010.08.002

[19] Sato, K., Ohashi, C., Ohtsuki, K. and Kawabata, M. (1991) Type V Collagen in Trout (Salmo gairdneri) Muscle and Its Solubility Change during Chilled Storage of Muscle. Journal of Agricultural and Food Chemistry, 39, 1222-1225. http://dx.doi.org/10.1021/jf00007a005

[20] Saito, M. and Marumo, K. (2010) Collagen Cross-Links as a Determinant of Bone Quality: A Possible Explanation for Bone Fragility in Aging, Osteoporosis, and Diabetes Mellitus. Osteoporosis International, 21, 195-214. http://dx.doi.org/10.1007/s00198-009-1066-z 